\title{
The Concepts of Trademark Exhaustion and Parallel Imports: A Comparative Analysis between the EU and the USA
}

\section{Samuel Dobrin}

Lund University Bildstensvägen $4 \mathrm{H}-2$, Lund 22654 , Sweden E-mail: samuel.dobrin@gmail.com

\section{Archil Chochia}

Tallinn Law School, Tallinn University of Technology Akadeemia tee 3

Tallinn 12618, Estonia E-mail: archil.chochia@ttu.ee

\begin{abstract}
The article intends to analyze the closely correlated concepts of trademark exhaustion and parallel imports. The growing importance of these concepts in the current world, especially in the European Union, makes it an interesting research topic, even though the concepts are complicated due to their nature and different actors involved. The authors use comparative approach, concentrating on two world leaders in the field, in order to discover what is the approach of the EU as well as the approach of the USA to the concepts of trademark exhaustion and parallel imports, what are the benefits and weaknesses of these approaches, and analyze why these markets have arrived at certain conclusions.
\end{abstract}

Keywords: EU Law, European Union, parallel imports, trademark exhaustion, USA 


\section{Introduction}

The concept of parallel importation is a constantly growing phenomenon in the current globalized world. Parallel importation refers to a situation where the proprietor of the trademark has not given its consent to import its trademarked goods to a certain area (Avgoustis, 2012, pp. 108-109). There may be several reasons as to why this kind of phenomenon occurs, but usually the most common reason is the price. It should be noted that these products are genuine trademarked products, but there are reasons why parallel imports may be seen as problematic (Vrins \& Schneider, 2012; Jehoram, Nispen \& Huydecoper, 2010, pp. 562-568). A closely correlated concept with parallel imports is the principle of trademark exhaustion. It can be seen that the approach to parallel imports will greatly depend on how a country deals with the question of trademark exhaustion. There are at least three possible views to this concept: national, regional and international. In the national approach, the rights of the owner of the trademark are seen to be exhausted only in that specific domestic territory where the trademarked products are placed by the owner or with his or her consent. The proprietor of the trademark has greater freedom to decide whether to place his trademarked products in different states or not (Calboli, 2002, pp. 48-49). International exhaustion of trademarks takes an opposite approach in comparison with the national approach, as the exclusive rights of the trademark proprietor to the trademarked product are exhausted internationally (the proprietor of the trademark cannot oppose the importation of his trademarked products into other states of the world). It can be stated that the international exhaustion promotes more efficiently the free movement of goods within international trade compared to the national approach. However, those states that do not accept the principle of international exhaustion may not accept these internationally exhausted products to their territory if the trademark proprietor does not give his consent (Verma, 1998). According to regional exhaustion, the rights of the trademark proprietor are exhausted in the whole region or community when the trademarked products are placed in one state of the community. The trademark proprietor cannot oppose to parallel imports coming from another state within the community. However, the trademark proprietor may control the trademarked products coming from outside the community. An example of a regional community that applies the rule of regional exhaustion of trademarks is the $\mathrm{EU}$ (Cook, 2010).

Trademark can be seen as a monopoly which protects the trademark itself and its proprietor's wishes. The doctrine of exhaustion of trademarks is seen as a limitation to these rights of the trademark proprietor. An equivalent name for 
this doctrine of exhaustion of trademarks that reflects the above idea is aptly the "first sale doctrine". There can be a situation in which after a trademarked product enters the marketplace and a consumer acquires it, this consumer may freely decide whether to resale the product or even destroy it (Sardina, 2011, pp. 1055-1061).

However, depending on the view of national, regional or international exhaustion of trademarks, this trademarked product may be exhausted only in a certain area. This means, for instance, that the products that are exhausted only in one country may not be imported to another country without the consent of the trademark proprietor. Since there is a close correlation with the concepts of trademark exhaustion and parallel imports, both concepts shall be properly analysed (Peatman, 2014, pp. 446-449). Therefore, this article intends to analyse the closely correlated concepts of trademark exhaustion and parallel imports. As an effective tool, comparative approach shall be used in order to identify the approaches of the EU as well as the USA to the concepts of trademark exhaustion and parallel imports, the benefits and weaknesses of these approaches, and analyse why these markets have arrived at certain conclusions.

Naturally, consumers want to have the best quality trademarked products at a low price. If parallel imports are indeed offering lower prices for the consumers and that way benefitting them, it can be asked, for example, why there is even a possibility for trademark proprietors to oppose parallel imports in certain situations. Therefore, the question of trademark exhaustion, and thus the approach to parallel imports, is increasingly relevant (Maskus, 2010, pp. 123132).

From the EU perspective, the Directive 2008/95/EC of the European Parliament and of the Council of 22 October 2008 (EC, 2008) to approximate the laws of the Member States relating to trade marks (EU TM Directive) is relevant in order to better understand what a trademark is. ${ }^{1}$ According to Article 2 of the EU TM Directive, "a trade mark may consist of any signs capable of being

\footnotetext{
As an interesting fact it can be stated that a new recast version of this EU TM Directive has been recently published as a Directive (EU) 2015/2436 of the European Parliament and of the Council of 16 December 2015 to approximate the laws of the Member States relating to trademarks (New EU TM Directive). However, as can be understood, this new directive is not yet applicable since there is a transposition period until 15 January 2019. After this date, the New EU TM Directive will become applicable whether the Member States have managed to implement the rules of this directive or not. Although, it is proper to note that this New EU TM Directive does not bring any radical interpretational changes to our concepts of trademark exhaustion and parallel imports.
} 
represented graphically, particularly words, including personal names, designs, letters, numerals, the shape of goods or of their packaging, provided that such signs are capable of distinguishing the goods or services of one undertaking from those of other undertakings." It is aptly stated in Recital 11 of this EU TM Directive that a trademark is, or should be, there to guarantee the indication of origin (EC, 2008).

Trademarks are not trivial but they have their own functions; from a consumer's perspective, trademarks are important when making a buying decision, they work as an assurance that the product is of the quality that the consumers have been used to, trademark means that the trademark proprietor invests in the trademark itself in order to make it known. These kinds of investments of the trademark proprietors deserve protection, which on the other hand makes the question of trademark exhaustion and parallel imports particularly difficult (Cornish, Llewelyn \& Aplin, 2010; Nyman-Metcalf, Dutt \& Chochia, 2014).

\section{Trademark exhaustion and parallel imports from the perspective of the EU}

\subsection{The approach of the EU to trademark exhaustion}

Although Digital Single Market and its possible benefits have become the main priority in the EU in securing the Europe's competitiveness in the world, practising the four freedoms has been often a battlefield between Member States (Kerikmäe \& Dutt, 2014). Since the doctrine of exhaustion of trademarks influences the trademark proprietors' ability to control economic distribution, this doctrine has been an important object of discussion in the EU, from the perspective of creating a more unified internal market within the Community. The international approach, on the other hand, would be a possibility, but obviously, the positive and negative effects should be weighed before deciding. The European Economic Community (EEC) was established in the 1957 for the reasons of creating a single unified market that would benefit its Member States. In order to achieve this goal, the economic barriers between the Member States were to be eliminated, so goods and services could move freely within this single market. While IP rights are monopolistic rights in a sense that the

2 The United States Trademark Act of 1946, as amended, distinguishes between the terms trademark and service mark. However, in this thesis we are not going to make a similar separation between these terms. We are going to follow the line of the EU TM Directive that applies a trademark term to both goods and services. (See, e.g., Arts. 1 and 2 of the EU TM Directive). 
trademark proprietor may control where its trademarked products are places, it contradicts the idea of the single market. Therefore, there was a need to prohibit national trademark exhaustion, and there was a need for the concept of regional trademark exhaustion (Craig \& Búrca, 2015).

Although Article 36 of the TFEU introduces an exception to this main rule by stating that Articles 34 and 35 of the TFEU "shall not preclude prohibitions or restrictions on imports, exports or goods in transit justified on grounds of public morality, public policy or public security; the protection of health and life of humans, animals or plants; the protection of national treasures possessing artistic, historic or archaeological value; or the protection of industrial and commercial property." The "protection of industrial and commercial property" is relevant in this research. However, the interpretation of this exception has been rather strict since it may seriously harm the functioning of the single market. As Article 36 of the TFEU states: "Such prohibitions or restrictions shall not, however, constitute a means of arbitrary discrimination or a disguised restriction on trade between Member States." (Craig \& Búrca, 2015).

As early as in 1974, the question of regional trademark exhaustion was clearly considered by the ECJ in the case of Centrafarm v. Winthrop [1974]. It was seen by the Court that the proprietor of the trademark could not prohibit the importation of his trademarked products, which was either marketed by the proprietor of the trademark himself or by his consent, from another Member State of the community. It is well stated by the Court that if this would not be the case in the community, the trademark proprietor could partition off the national markets, restricting the trade between Member States, which was not the goal of the EEC in the past, and it is not the goal of the EU today (Ohly \& Pila, 2013, pp. 108-111).

Eventually, as a compromise between international and national approach, the principle of "Community-wide exhaustion" (regional approach) was recognized in Article 7 of the First Council Directive of 21 December 1988 (EC, 1988) to approximate the laws of the Member States relating to trademarks (First TM Directive) which is now replaced by the EU TM Directive. From 1 January 1994, Article 7 of the First TM Directive was also extended to the EEA. Shortly, Article 7(1) now states that a trademark owner cannot prevent the importation of a good from a Member State to another Member State if the good is legitimately put on the circulation of the first Member State's market. Article 7(2) of the First TM Directive ${ }^{3}$ makes a certain exception when Article 7(1) does not apply (Cornish, Llewelyn \& Aplin, 2010).

3 The wording of Article 7 in both the First TM Directive and the EU TM Directive is similar. 
Due to unclear wording, the Court of Justice had to clarify this issue through case law and stated in several decisions that Article 7(1) shall be interpreted as a general principle that does not allow the Member States to apply international exhaustion within the EU. ${ }^{4}$ However, at the beginning of 2000, certain European institutions and other parties still wanted to consider whether international exhaustion could be a possible or a more desirable alternative instead of Community-wide exhaustion, but no change was made to Article 7(1) of the First TM Directive. Some commentators have aptly stated that this protectionist method supports the idea of "fortress Europe" (Calboli, 2012, pp. 258-260; Jehoram, 1999).

\subsection{Parallel imports from outside the EU}

The situation prior to the harmonization of the EU's trademark law regarding the question of international exhaustion of trademarks, and thus the question of nonEU parallel imports, was rather different than it is today. The rule was that the question of parallel imports, which were imported from outside the Community, was not to be considered by the EU law. This outcome was concluded in the case EMI v. CBS [1976]. It was seen that the present Article 34 of the TFEU was to be applied only between Member States. Therefore, only parallel imports from within the EU were to be considered by the EU law. Naturally, this meant that each Member State had their own discretion to decide how to approach the question. While some preferred the rule of international trademark exhaustion, others did not. The decision of EMI v. CBS made this discretion of Member States possible (Norman, 2011, pp. 424-425).

An additional case clarifying the abovementioned ruling of $E M I v . C B S$ is the case of Phytheron International SA v. Jean Bourdon SA [1997]. This case simply recognizes the fact that when a trademarked product has lawfully entered the EU, this product becomes exhausted in the whole Community. It does not matter whether some Member States have different approaches to the trademark exhaustion. Once put to the market of one Member State with the trademark proprietor's consent, these goods are seen as Community goods (Avgoustis, 2012, pp. 115-116). Despite the abovementioned clarification case, it did not change the main idea of EMI v. CBS: each Member State may still have different approaches to the trademark exhaustion. The fact is that the doctrine

4 See, e.g., Silhouette International Schmied GmbH \& Co. KG v. Hartlauer Handelsgesellschaft mbH [1998]; Sebago Inc. and Ancienne Maison Dubois \& Fils SA v. G-B Unic SA [1999]; Zino Davidoff SA v. A \& G Imports Ltd and Levi Strauss \& Co. and Others v. Tesco Stores Ltd and Others [2001]. 
of trademark exhaustion is a highly debatable concept, meaning that there is no uniform attitude towards this concept, even inside the EU.

In order to create a more unified internal market where the trademarked goods will move as freely as possible, the harmonization of trademark law within the EU was seen as necessary. The outcome of this goal was the First TM Directive, established in 1988. Article 7(1) states: "the trade mark shall not entitle the proprietor to prohibit its use in relation to goods which have been put on the market in the Community under that trade mark by the proprietor or with his consent." Thus it incorporates the idea of regional Community-wide exhaustion. Despite this, it can be seen that the question of non-EU parallel imports are not clarified. It is argued that it is unclear whether this paragraph works as a minimum standard which would still allow its Member States to apply international trademark exhaustion. In other words, it is unclear whether the ruling of the EMI v. CBS is still applicable. The question was, and remains today, rather complex. Both regional and international approaches have their positive and negative aspects. Now, the question is whether the Court of Justice is satisfied with this outcome or is there a need for clarification (Calboli, 2012, pp. 60-66).

For the sake of uniformity, for instance, the Court of Justice decided to give their judgement answering to the abovementioned concern. In 1998, the case of Silhouette International Schmied GmbH \& Co. KG v. Hartlauer Handelsgesellschaft $\mathrm{mbH}$ [1998] was settled that quite clearly states the approach of the Court of Justice to the question of international trademark exhaustion and to the parallel imports coming from outside the Community. Although, technically speaking, it is argued that the case of Silhouette is not a pure non-EU parallel import case but rather a re-importation case. Therefore, it is argued whether Silhouette is the case to provide an appropriate answer to the non-EU parallel import question (Bently \& Sherman, 2009, pp. 953-958).

The Court of Justice wished to clarify the situation by stating that the doctrine of international exhaustion is not allowed to be used by its Member States. It can be seen that the ruling derived from the case EMI v. CBS no longer applies. The only applicable approach in the EU would be the regional Community-wide trademark exhaustion. This would mean, as in the case of Silhouette, that the trademark proprietor would have the right to prohibit parallel imports coming from outside the EU. It was seen by the Court of Justice that the international exhaustion of trademarks would reduce the protection of the trademark proprietors too drastically. As to further reasoning, it was emphasized that it is in the best interests of the internal market to have a single approach, Community- 
wide exhaustion, in order to ensure, for instance, that the trademarks receive the same level of protection in all the Member States. This, on the other hand, will facilitate the free movement of goods and services as efficiently as possible (Michaels \& Norris, 2010).

The decision of the Court of Justice received a lot of criticism for the reasons of creating a "fortress Europe". This concept reflects the ideas of control and protectionism. Naturally, the approach of regional trademark exhaustion is indeed a compromise between national and international trademark exhaustion that offers more control to the trademark proprietors, but seems to be restrictive for the other actors of the Community, such as consumers. Furthermore, as mentioned above, it is also argued that the case of Silhouette is not a pure non-EU parallel import case but rather a re-importation case. After all, the trademarked products of Silhouette were originally from the Community as well as intended for the market of the Community, making these spectacles EU products. Therefore, the Court of Justice ignored the question of the function of origin the trademark to some extent (Abbott, Cottier \& Gurry, 2011, pp. 90-98).

Despite the extensive criticism towards the decision on the Silhouette, the view of the Court of Justice did not seem to change. For instance, quite soon after Silhouette the Court confirmed its view on the case of Sebago Inc. and Ancienne Maison Dubois \& Fils SA v. G-B Unic SA [1999], basically, Member States shall not apply the doctrine of international trademark exhaustion. First of all, this case was not about re-importation but clearly about non-EU origin parallel import. The Court of Justice was quite clear that the trademark proprietor's consent is necessary for the parallel import to be accepted. What is also noteworthy about the Sebago case is the question of implied consent that was raised in the proceedings. The question was whether consent was to be considered as given for subsequent identical or similar trademarked products. The Court of Justice admitted that the wording of Article 7(1) of the First TM Directive does not give a direct answer. However, the Court of Justice clearly concluded that the consent should be given for each individual stock of goods rather than for whole product lines. Therefore, it can be concluded that the view of the Court of Justice remains strict against international trademark exhaustion and thus against nonEU parallel imports (Keeling et al., 2014).

In several upcoming cases till this day, the Court of Justice has consistently followed the reasoning of the Silhouette and Sebago. Clearly, it can be seen that the rights of the trademark proprietor are seen as significant in the context of non-EU parallel imports. For instance, from the joined cases of Zino Davidoff $S A$ v. A \& G Imports Ltd and Levi Strauss \& Co. and Others v. Tesco Stores Ltd 
and Others [2001] this abovementioned fact becomes rather clear. First of all, in addition to the fact that the Court of Justice reaffirmed the Community-wide exhaustion as the only applicable approach in the Community, the concept of consent was further analysed. The Court of Justice clearly stated that the concept of "consent" is up to the EU law to be construed, and therefore, the Member States shall not analyse it according to their own laws. The Court of Justice clarified that the burden of proof shall be on the parallel importer to show the unequivocal express consent of the trademark proprietor. It is stated that implied consent may be given, but only in exceptional cases. Clearly, the Court of Justice did not want to reduce the rights of the trademark proprietor. However, despite the strict idea of the regional approach to the trademark exhaustion, it should be noted that there is still a possibility for the Member States to adopt the principle of international trademark exhaustion through bilateral or multilateral treaties with third countries. This may raise the question whether there would be a possibility for the common approach of the EU to change to a more liberal one supporting the idea of international trademark exhaustion (Birstonas \& Klimkeviciute, 2014, pp. 94-96; Griffiths, 2011, pp. 70-80; Shen, 2012, pp. 191-192).

\section{Trademark exhaustion and parallel imports from the perspective of the USA}

The first significant case regarding the trademark exhaustion in the USA was given already in the year 1886. In this case of Apollinaris Co. Ltd. v. Scherer [1886], the Court recognized the principle of "universality" of trademark rights. Therefore, the international trademark exhaustion was approved allowing genuine trademarked products to be imported as parallel imports to the USA. It was seen by the Court that the essential function of the trademark, the origin function, was not negatively affected by the parallel importation. The Court stated that there was no risk of confusing the consumers of the origin of the trademarked product whether it was imported through authorized distribution channels or as a parallel import. Therefore, the view of the Court was more favourable to the consumers (Grigoriadis, 2014, pp. 429-439).

However, in 1923 the United States Supreme Court decided to adopt a surprisingly different approach which would emphasize the right of the trademark proprietor. In the case of A. Bourjois \& Co. Inc. v. Katzel [1923], the concept of "territoriality" of trademarks was strictly recognized. The Supreme Court confirmed the fact that trademarks should be recognized differently in each 
national territory. It was recognized by the Supreme Court that the trademark proprietor has invested significantly to the marketing of the product in the USA, increasing the goodwill of the trademarked product and thus the public of the USA has become accustomed to deal especially with the trademarked products coming from the official distribution channels. The Supreme Court recognized the fact that the trademark has been assigned to the trademark proprietor in the market of the USA, and therefore it would not be correct for other parties to compete with the trademark proprietor, international trademark exhaustion was no longer seen as a suitable approach in the USA(McCarthy, 2016). The Supreme Court understood the difficulty in balancing the rights between different actors, namely between the trademark proprietors and the consumers, and decided to emphasize the rights of the trademark proprietor (Altman \& Pollack, 2015).

The current approach of the USA to the question of trademark exhaustion and parallel importation has evolved from the Katzel case. Even though the idea of national trademark exhaustion still exists, granting the trademark proprietors the right to block parallel imports coming from outside the USA, the approach of the USA towards parallel imports has changed to a more liberal one, allowing parallel imports in certain situations.

First of all, there is a situation called "round trip scenario", which basically allows trademarked products to be imported to the USA if they were originally manufactured in the USA. This ruling can be derived directly from the legislation of the USA. ${ }^{5}$ The second exception to the main rule of national trademark exhaustion is the so-called "common control" exception. This exception was first introduced in 1972 in the Customs Regulation of that time. ${ }^{6}$ This states that the trademark proprietor cannot prohibit parallel imports in certain situations, namely when the same person or entity owns both the foreign and the USA based trademark. Furthermore, parallel imports cannot be opposed when the domestic and foreign trademarks are owned by subsidiary or parent companies, or by companies "otherwise subjected to common ownership and control". Thirdly, parallel imports may not be opposed when the authorization to use the trademark by the foreign manufacturer is acquired by the trademark owner in the USA (Calboli, 2011, pp. 1258-1265).

The trademark proprietors in the USA saw these new provisions as inconsistent with the earlier given law. ${ }^{7}$ They were especially worried about the fact that an unrelated third party could acquire the trademarked products from the

5 See 19 US Code $\S 1526($ a).

$6 \quad$ See 19 CFR § 133.21(c).

7 Namely with the 19 US Code $\S 1526$. 
foreign subsidiaries, for example, and then sell them as parallel imports to the USA without authorization. Obviously, these parallel imports would compete with the local trademarked products of the USA. Therefore, the validity of the abovementioned provisions was questioned in the case of K-Mart Corp. v. Cartier, Inc. [1988]. Despite the concerns of the trademark proprietors, the Supreme Court confirmed the first two points of the "common control" doctrine, but rejected the third "authorised use" exception, as being in conflict with the "unequivocal language" of the earlier law. All in all, this was a rather remarkable step away from the strict national approach to the trademark exhaustion, and to the parallel imports (Cheng, 2012, pp. 175-181).

However, the Supreme Court of the USA was not done with the question of parallel imports. It can be seen that "material differences" rule, also known as the "material quality differences" (MQD) rule, was presented which gave the trademark proprietors an opportunity to prohibit parallel imports when the trademark products were not identical, but had certain material differences. This is the case even for those trademarked goods that fall under the common control doctrine mentioned above. It is true that this rule may seem restrictive, but the logic or reasoning behind this rule is closely correlated with the concept of "likelihood of confusion". Even if the parallel import is genuine, it should not be imported if it may deceive the consumers of the origin or nature of the trademarked product by being physically different than the other trademarked product intended for the market of the USA (Abbott, Cottier \& Gurry, 2011, pp. 406-420).

An example of a situation where the "material differences" rule was applied is the case of Lever Brothers Company v. United States [1993]. Here the affiliated companies Lever Brothers Company (Lever US) and Lever Brothers Limited (Lever UK) both used the same trademark "Shield" for their soaps, but the fact was that these soaps were substantively of different quality. The Court granted the Lever US the right to prohibit the parallel imports coming from the United Kingdom for being "materially different" and causing "consumer confusion". The Court also emphasized the fact that the affiliation between the companies did not matter. It is argued that the Lever Brothers case, in addition to other similar cases, is a good example of a case that is there to protect the consumers from the risk of being confused to acquire genuinely different trademarked products than intended (Grigoriadis, 2014, pp. 439-451).

However, in the quite recent case of Zino Davidoff SA v. CVS Corporation [2009], the relevant Court stated rather aptly that the "low threshold of materiality" is applied, which means that even a slight difference in the trademarked product may cause that product to be "materially different" if it is seen that the consumers 
would consider this difference as a relevant factor when purchasing the product. In the Zino Davidoff SA case itself, the question was about production codes that were taken off from the parallel imports. Despite the fact that the parallel imports were genuine products, it was seen that the production codes were a significant part of the fragrance bottles. It can be seen that the trademark proprietor attached these codes as a "quality control mechanism" in order to identify counterfeit products from the genuine ones, as well as to identify defective products. Therefore, the removal of these production codes, even if it seemed as a small difference, was seen to impair the reputation, or goodwill, of the Davidoff's trademark by undermining the quality control mechanism. From the consumer's perspective, this is a rather logical argument since the lack of production codes may raise suspicions whether the trademark product is genuine or defective, and that way affect the purchasing decision (Avgoustis, 2012, pp. 115-117).

It is well argued that the "low threshold of materiality" may work properly in certain cases, but sometimes the threshold is relatively low causing debatable judgements, which on the other hand causes uncertainty. A case of Martin's Herend Imports, Inc v. Diamond \& Gem Trading USA [1997] shows that there was not actual physical material difference in the parallel imports since they were genuine trademarked products manufactured in the same factory as the ones in the US market. However, what makes this case interesting is the fact that the trademark proprietors for this specific market individually selected the trademarked products, luxury high quality porcelain products, which were sold in the US market. What this means is that the factory manufactured numerous pieces of same quality products, but not all of them were chosen to be sold in the USA. The colours, patterns or shapes of the porcelain products were different between parallel imports and those intended for the US market. The Court argued that the luxurious goodwill of the trademark in the USA is greatly affected, for instance, by the fact that the products have their own style specially chosen by the trademark proprietors for the US market. Therefore, the Supreme Court saw that the parallel imports of different style not intended for the market of the USA could erode the luxurious goodwill achieved in the USA, and therefore, material difference was seen to exist. It can be argued that this judgement may favour the trademark proprietors more than the consumers by restricting the selection of products, for example. However, especially in the cases of luxury products, this is not as simple as it may seem since the distinctive goodwill of the trademark is worth protecting. Otherwise, this trademarked product would not be seen as a luxury product in the first place (Zappalaglio, 2015, pp. 69-73).

Even if the threshold for the material difference is rather low in general, it is worth noting that there is still a possibility for materially different parallel 
imports to lawfully enter the territory of the USA. Namely, as an exception to the Lever Brothers rule, a safety valve was adopted in the Customs Service Regulations describing that with a proper labelling it would be possible to avoid detention of the parallel import. This labelling shall state in a legible and clearly visible manner that: "This product is not a product authorized by the United States trademark owner for importation and is physically and materially different from the authorized product." " This exception is a rather convenient way of decreasing the chance for consumer confusion. By this kind of labelling, the consumer clearly understands that the product is "materially different", and will make its own choice whether to acquire the product or not. At the same time, this can be seen as rather positive for the parallel importer, since the chance for detention of the parallel imports will be smaller, and that way the fear of losing profits will be more minimal. This kind of approach is definitely more positive towards parallel imports, which will, on the other hand, increase the idea of free trade (Calboli, 2011, pp. 1262-1265; McCarthy, 2016).

\section{Different approaches to the trademark exhaustion and parallel imports-the comparison of the EU and the USA}

When comparing the approaches of the EU and the USA to the concepts of trademark exhaustion and parallel imports, it cannot be denied that the approach of the EU is more cautious in general in comparison to that of the USA. However, the USA does not apply the most liberal view, namely the international approach, to the trademark exhaustion either. In this sense, these markets have something in common.

There are different possibilities to approach the concept of trademark exhaustion, and thus parallel imports, such as a national or regional approach. All these approaches have their own positive and negative aspects. It would be convenient for every country in the world to apply international trademark exhaustion in order to create a global market where consumers could basically acquire anything through parallel imports. Obviously, this would be the optimal solution from the view of free movement of goods, but at the present moment, there seems to be too many concerns regarding this view. This view would minimize the control of the trademark proprietor, which is a debatable question. It can be asked whether the countries are ready to give up this much control for the sake of free trade for example (Rai \& Jagannathan, 2012, pp. 74-77).

$8 \quad$ See 19 CFR $\$ 133.23(b)$. 
To begin with the approach of the EU, the rights of the trademark proprietors are respected rather well, since the trademark proprietors are granted the possibility to prohibit parallel imports coming from outside the EU without any reason. As can be understood, the approach of the EU represents the idea of regional approach to the trademark exhaustion, meaning that the same benefits and weaknesses of the national trademark exhaustion exist in a certain extent, the regional approach simply expands the territorial scope of the national trademark exhaustion. Of course, the regional approach to the trademark exhaustion is more liberal than national approach, but it still raises suspicions why it would be more beneficial for the consumers than the international exhaustion, for instance. After all, the consumers are not offered the possibility to choose for themselves whether to buy non-EU parallel imports or not. Rather, it is seen as more appropriate to leave the trademark proprietors to decide whether non-EU parallel imports are accepted in the Community (see, e.g., INTA, 2015).

The approach of the EU may seem rather restrictive but there are certain reasons why the Court of Justice, for example, supports this view. Firstly, especially in a case of multinational companies, the trademark proprietor may supply trademarked products in different markets, but sometimes these trademarked products, even if they hold the same trademark in every territory, may slightly differ from each other. This method is sometimes called a "product differential strategy" (Chen, 2009, pp. 33-34). The packaging, design or sales network of the trademarked product may vary between each territory. For example, depending on the trademarked product, there may be different kind of health requirements in each market territory, resulting in materially different products. Therefore, it may be for the advantage of the consumer not to acquire these products. It can be seen that by leaving the trademark proprietor the possibility to prohibit non-EU parallel imports, the control of the quality of the trademarked products are better ensured. Although, from the other perspective, it can be asked whether this kind of monopolistic control of the trademark proprietor is genuinely beneficial for the consumers and the Community as whole. Could it be that the trademark proprietor may want to use this power of control abusively for anti-competitive reasons? (Abbott, Cottier \& Gurry, 2011, pp. 90-98, 340-342).

Which is also beneficial about the approach of the EU, is the fact that it can be seen as more predictable. Although it can be still argued that despite the fact that the trademarked products are identical, the distribution channel for parallel imports is not the same as it is for the authorized products, which can be seen as a negative fact for the consumer. For instance, the question of after-sale services or guarantee may became relevant since there is no obligation for the trademark proprietor, or for the parallel importer, to grant these kind of services 
for parallel imports. Nevertheless, depending on the perspective, by adopting a stricter approach, as the EU has, the negative consequences of the non-EU parallel imports to the consumers are avoided, while at the same time the legal certainty will remain unambiguous. While the consumers are protected, the parallel importers will also know that non-EU parallel imports are not accepted without the clear consent of the trademark proprietor, and will not, therefore, bother importing these products to the EU. If there is no imported trademarked product in the first place, there is no risk of detention either (LaFrance, 2009, pp. 297-311).

Despite the certain weaknesses of non-EU parallel imports, the fact of having more selection and lower prices can be a great benefit for the consumers. For instance, as to the above argument about after-sale services and guarantees, it is argued that with appropriate knowledge, consumers will realise that the product being bought is a parallel import from an unauthorized distributor, which means that the after-sale services or guarantees may not be included. Therefore, when comparing the approaches of the EU and the USA in this regard, the "material differences" approach of the USA can be seen as more favourable to the consumer in providing a larger selection of affordable parallel imports (Bonadio, 2011, pp. 153-156).

While this may be true, the approach of the USA can also be seen less predictable than the approach of the EU. This is mainly due to the threshold that is included in the material differences approach. The usage of threshold will inevitably cause debatable situations where a parallel importer is not certain whether the trademarked product will be recognized as a parallel import or as a materially different product. ${ }^{9}$ Especially in the case of the USA, this threshold is relatively low, which increases the risk of parallel imports to be recognized as materially different, and therefore, to be detained. Of course, as argued in the fifth chapter, the parallel importer can always take a risk and use the exception to the Lever Brothers ruling where the materially different parallel imports will not be detained if they are properly labelled. However, it might be more difficult to sell these trademarked products if they are labelled as materially different, and therefore, the risk of revenue loss can be significant. Furthermore, this kind of legal uncertainty is not beneficial for the consumers either, since the parallel importers may be less willing to import if there is an uncertain chance of detention. As the case law of the USA above demonstrates, this "material differences" approach usually works rather well, but is not perfect because of its relatively low threshold (Zappalaglio, 2015, pp. 71-75).

9 See, e.g., the above cases of Zino Davidoff and Herend. 
Despite the fact that the approach of the EU does not seem perfect, there are other benefits as well. For instance, a benefit of the approach of the EU can be seen in research and development (R\&D). The trademark proprietor has invested a lot of capital and time into developing the trademarked product. This R\&D, for example, may include innovations and improvements to the trademarked product. Without this expensive $R \& D$, there would not be a finished unique trademarked product in the first place. In addition to $R \& D$, the concept of "goodwill" or reputation of the trademark might be extraordinary. There are many factors that increase the goodwill of the trademark, and thus the reputation of the trademarked product itself, such as marketing. Naturally, these investments are not free of charge. Now, the concept of R\&D is worth protecting in order to benefit the market as a whole. The reason why the approach of the EU may be seen as beneficial is that it is stricter against non-EU parallel imports, leaving the trademark proprietor power to decide whether to approve these parallel imports. Since the trademark proprietor will not be forced to compete with its own trademarked products, this will, on the one hand, encourage the trademark proprietors to invest more in $\mathrm{R} \& \mathrm{D}$. This, on the other hand, can be seen to benefit the consumers as well: for example, consumers will have the opportunity to enjoy the fruits of new innovation (Maskus, 2010, pp. 123-132). However, in certain cases, without parallel imports, consumers would not necessarily even buy the authorized product, for example, if it is too expensive. Therefore, owing to the parallel imports coming from outside the Community, the sold units can be even higher than without parallel imports. Furthermore, it can also be argued that the trademark proprietor receives its revenue already at the moment when the parallel importer acquires these products from the appropriate foreign market. In that sense, the trademark proprietor has already acquired its profits for the R\&D costs. Although, the question whether the parallel imports coming from outside the community will decrease the incentive of the trademark proprietor to invest in the R\&D, is not as simple as it may seem (Shen, 2012, pp. 190-192).

First of all, heavy investments to the R\&D are not that relevant for every firm. Certain trademarked products do not require continuous investments in $R \& D$, while others do. For instance, continuous heavy investments in $R \& D$ are usually relevant in the pharmaceutical industry. The problem that now arises is the fact that the firms' willingness to invest in $R \& D$ greatly depends on the expected profit. It is argued that the parallel imports will greatly diminish the preliminary estimations of the firm to cover these R\&D costs, since the trademark proprietors often use different prices for different markets. Now, the consumers in wealthier countries, where the prices are usually higher than in developing countries, will more likely buy cheaper identical parallel imports and this may 
lead to a situation where the authorized more expensive trademarked products will not be sold at all. These more expensive products usually have the highest profit margin as well. Moreover, the profit from the parallel imports goes to the parallel importers, who are not required to compensate for the expensive R\&D costs. Therefore, it is argued that the firms would be less willing to invest in $R \& D$ if the parallel imports are allowed worldwide. With no doubt, it is more convenient and encouraging for the trademark proprietor to acquire the potential expected profits if there are no identical parallel imports to compete with. That is why the stricter approach of the EU towards non-EU parallel imports may be more beneficial in increasing the willingness of the trademark proprietors' to invest more in R\&D (Mueller-Langer, 2012, pp. 180-181; Maskus, 2006, pp. 449-454).

Another relevant benefit of approaching the concepts of trademark exhaustion and parallel imports more cautiously is the fact of avoiding the abuse of trademark's goodwill. The reason why unauthorized parallel imports are seen as a threat that parallel importers may get a "free ride" with this goodwill or reputation of the trademark by simply appropriating these trademarked products at a favourable price and then sell them in the target market more expensively. Naturally, the trademark proprietor may not be satisfied with the fact that he is forced to compete with his own products that may be identical or slightly different. On the other hand, while this question of free riding may be morally debatable, parallel imports are still genuine trademarked products acquired legally. It can be asked whether the trademark proprietors deserve this kind of additional protection to prohibit parallel imports. In the end, parallel imports can be seen as products that are simply resold (Avgoustis, 2012, pp. 117-121).

When considering the reasons for the EU and the USA to approach the concepts of trademark exhaustion and parallel imports as they do, there is no definitive answer. These concepts are rather difficult to approach in a way that would be satisfactory for all the relevant actors of a market. Especially the approach of the EU seems rather overprotective against non-EU parallel imports, making it seem that the consumers' rights are not similarly respected as the rights of the trademark proprietors. From the perspective of genuine free trade and consumers' chance for wider selection, the best approach would seem to be international exhaustion. However, as seen above, international exhaustion would also bring many concerns that seem too significant to be ignored (Rai \& Jagannathan, 2012, pp. 74-77). When choosing a way to approach the concepts of trademark exhaustion and parallel imports, each market uses their own interests as a general basis. No doubt, the rights of the consumers are strongly recognized in both markets, but whether it is truly the main goal of the market to 
promote these rights of consumers as far as possible seems to be debatable. First of all, in the case of the EU, it can be observed that one of the primary goals of the EU is to create a strong internal market, meaning, for example, that goods, including parallel imports from within the EU, should move freely within this Community. When focusing primarily on this sole interest of the EU to maintain a successful internal market, the regional trademark exhaustion seems as an appropriate choice. This kind of protectionist approach does not fully support the idea of a worldwide free trade, but rather creates a juxtaposition between the EU and the rest of the world. However, it is well argued that this idea is a strategy in itself. After all, by regional trademark exhaustion, the needs of an internal market are satisfied while the negative effects of the international trademark exhaustion are avoided. Of course, the benefits of a liberal approach are not enjoyed, but it seems that the EU is satisfied with this fact for now (Peatman, 2014, pp. 463-465; Calboli, 2012, pp. 258-260; Jehoram, 1999).

However, the EU has considered the possibility of applying the international approach as well, which would allow the non-EU parallel imports to the Community without the consent of the trademark proprietors. This would also open the possibility of non-EU parallel imports from the USA. An important guidance that was used to see whether international trademark exhaustion would be preferable was the usage of an empirical study. As can be seen from the case law of the Court of Justice as well, the relevancy of deciding whether to apply the approach of the international trademark exhaustion has been especially heated at the turn of the $21^{\text {st }}$ century. ${ }^{10}$ Therefore, the European Commission asked the National Economic Research Associates to prepare a study (NERA, 1999). The goal was to determine the effects that the Community-wide exhaustion would have to the EU in comparison to the international exhaustion. It was relevant to identify the potential effects the non-EU parallel imports would have to the general wellbeing to the Community (MacGillivray, 2010, pp. 33-35; Calboli, 2002, pp. 83-87).

The outcomes derived from the NERA Study were not unambiguous. Facts supporting both the regional and international trademark exhaustion could be found. Nevertheless, based on the findings of this study, it was seen that the existing Community-wide exhaustion was generally sufficient for the EU, although this decision was a compromise since many actors, including the Member States, were still divided on this issue even after the NERA Study. The main argument favouring the regional approach was the fact that it would protect the competitiveness and innovation of the Community, since it would

10 See, e.g., the case of Silhouette. 
ensure that the trademark proprietors would receive their investment back from new endeavours. Furthermore, it was argued that the EU would not fully benefit from the international trademark exhaustion since all the other trading partners, including the USA, do not apply the international approach reciprocally. One reasoning behind this argument is that this would create a situation where the parallel importers in the EU could not freely export trademarked products to other markets, while the parallel importers in other markets could freely bring parallel imports to the EU instead. While the reciprocal approach would definitely be more preferable for the reasons of profiting from parallel exports, it is aptly stated that the benefits derived from the parallel imports could be sufficient. Especially in the case of the EU, the prices are usually higher than in other markets, making parallel exports impractical, although this is highly dependable on the specific sector or product at hand (Zappalaglio, 2015, pp. 79-81).

As to the supporting arguments presented in the NERA Study for the international trademark exhaustion, it is stated, for instance, that non-EU parallel importers would reduce the prices of the trademarked products as well as increase the "inter-brand competition". Thanks to non-EU parallel imports, this competition would be increased since there would be a smaller possibility for a trademark proprietor to abuse his position in one particular brand market by raising prices in other brand markets. Furthermore, the international trademark exhaustion would be the preferable choice since the main function of the trademark legislation should be to assure the origin of the product, and not to influence as a tool to create market segmentation. It was also noted that there is not much evidence that non-EU parallel imports would cause consumer confusion (see EC, 1999).

In addition to these above arguments, the NERA Study itself was also criticized to a considerable extent. First of all, it was seen that the statistical results from this study were unreliable since for instance, the response rate of different enterprises was extremely low, less than three per cent of the original 5,500. In fact, NERA itself also admitted that the numerical estimations from the study should be treated with caution. Therefore, the true influence of the parallel imports may have been under-reported. Another relevant criticism of the NERA Study was the fact that the long-term effects of changing the present regime to the international trademark exhaustion did not receive enough attention. By focusing on the short-term effects, important long-term effects may have been missed. This is also noted in the NERA Study by recognizing that the long-term dynamic consequences are likely to be more important, but at the same time less easy to predict. Therefore, it is suggested that more up-to-date analyses should be conducted in order to have a more reliable picture of the benefits of international trademark exhaustion. Although, this does not seem likely on the 
EU level, taking into consideration the facts that the European Commission has not considered this topic in the past ten years, while the Court of Justice has consistently applied the Community-wide exhaustion without any exceptions regarding non-EU parallel imports (Maskus, 2000, pp. 1279-1283).

As to the case of the USA, certain facts should be kept in mind when trying to compare its approach to that of the EU. First of all, the historical roots of the USA concerning the concepts of trademark exhaustion and parallel imports are much older than those of the EU. The USA has had the possibility to modify its rules for decades as a unified single country. Also, when comparing the USA to the EU, the EU was originally comprised of a few Member States, but as the time has passed, the expansion has been quite remarkable. It is not easy to have a consensus between all Member States with their own interests in a relatively short period. After all, the markets of the EU Member States are rather different and for some the international trademark exhaustion may be more suitable than for others. In this regard, the internal market of the USA seems to be in a more favourable position owing to its longer history as a unified country (Shen, 2012, pp. 176-211).

The early case law of the USA emphasized the fact of universality. Based on this principle, the approach of international trademark exhaustion seemed as the most appropriate choice. However, as the upcoming case law demonstrates, the question of trademark exhaustion, and thus the question of unauthorized parallel imports, has become more complicated. The principle of universality is admirable for the sake of free trade, for example, but it seems logical to adopt the territoriality approach in order to better protect the interests of the trademark proprietors and consumers as well. As shown by the Katzel case, the question of goodwill became already relevant in the year 1923. The Supreme Court of the USA understood the idea of "free riding", where the parallel importer could take advantage of the trademark proprietor's significant investment on marketing, for instance. Therefore, it was seen that the universality approach could be easily abused, and that is why the territoriality approach would seem more satisfactory for the time being. However, as the current approach demonstrates, it seems that this mentality of emphasizing the universality has not been completely forgotten (Farley, 2014, pp. 49-54).

As observed from further case law, the approach of the USA has acquired many liberal traits despite not applying the international trademark exhaustion in full extent. As the case law demonstrates, an important emphasis in the discussion on how to approach the concepts of trademark exhaustion and parallel imports has been the idea of "consumer protection approach" and "unfair competition 
approach". The main idea of the consumer protection approach is to counterbalance the legal rights of the trademark proprietors and consumers together, against the legal rights of the parallel importer. Therefore, the rights of the trademark proprietor should be respected, including the goodwill of the trademark, while the consumer should be protected from deception and confusion. As a logical consequence, it is seen that this goal will be sufficiently fulfilled by applying the "common control" doctrine accompanied with the "material difference" rule. The common control doctrine is there to limit parallel imports, favouring the trademark proprietor's control. The material difference rule, on the other hand, is there to make sure that the nature and quality of the trademarked product corresponds to the standard that the consumers are accustomed with (Cheng, 2012, pp. 183-188). The unfair competition approach is there to balance the rights of all the relevant actors on the market, to take into consideration the consumers' right to access cheaper prices. On the one hand, owing to parallel imports, the market will be more competitive avoiding situations where the trademark proprietor may abusively keep the prices high. On the other hand, the legal interests of the trademark proprietor should also be taken into account. It can be asked whether the unauthorized parallel imports cause a situation of unfair competition where the trademark proprietor is forced to compete with its own products against parallel importers, who basically try to free ride with the trademark's reputation while undermining the official distribution channels. After all, as seen earlier, there are reasons why the trademark proprietor may wish to use different prices for different markets. The balancing of these different rights is rather difficult. Nevertheless, as the present approach of the USA demonstrates, these different rights are genuinely tried to be balanced in a sense that unauthorized parallel imports from outside the USA are allowed in certain conditions. This is a definitely more liberal approach than the one of the EU. Furthermore, the possibility for even a materially different product to be allowed to enter the territory of the USA, with appropriate labelling, is rather reasonable. Therefore, the current approach of the USA has managed to balance the rights of different actors rather well.

Whether the USA will apply the international trademark exhaustion in full extent remains to be seen, but certain implied steps are already taken towards this. It is well argued that recent developments in the field of copyrights could have an impact for the field of patents and trademarks as well. For example, in a recent case of Kirtsaeng v. John Wiley \& Sons, Inc. [2013], the Supreme Court applied the approach of international exhaustion instead of national exhaustion in the field of copyrights. It was seen by the Supreme Court that there was no actual evidence to show that the drafters of the relevant copyright legislation 
wanted to limit the first sale doctrine as territorially applicable. Therefore, it was seen proper to apply the rule of international exhaustion, and that way approve copyrighted works to be imported from outside the USA, without the consent of the copyright proprietor. It was seen that it is not relevant whether these copyrighted products are manufactured outside the USA as long as they are lawfully produced and marketed. Now, based on the Kirtsaeng case, it is not clear whether it will impact other IPRs as well. Some scholars have argued that this may be an important step towards an international exhaustion regime, and in our case, a possibility for international trademark exhaustion. However, when talking about international exhaustion in general, each IPR has to be considered individually. Therefore, no final conclusions can be made, but it is well stated that at least the discussion about the possibility of international exhaustion for other IPRs, has become relevant (LaFrance, 2013, pp. 63-72; Katz, 2016, pp. 1-10; Prutzman \& Stenshoel, 2013).

As to the possible unified approach between the markets of the EU and the USA, it seems unlikely for the time being, but not impossible. Despite the fact that these markets are, and will most likely remain, important trading partners, the current situation seems to demonstrate that these markets will try to focus primarily on their own interests, and develop their approach as they seem fit. For instance, based on the case law of the EU, the Court of Justice has consistently applied the approach of the Community-wide exhaustion. What this seems to imply is that the primary goal of the EU is to further develop as a strong single market. The unification process between the Member States of the EU is far from complete, which means that a cautious approach to the concepts of trademark exhaustion and non-EU parallel imports is understandable, as the EU may not be ready to apply more liberal rules. Although, it is worth keeping in mind that there is always a possibility for a mutual agreement, a free trade agreement for example, between the EU and the USA that would harmonize the rules concerning our concepts. In fact, it is suggested that Trans-Atlantic Trade and Investment Partnership (TTIP) could prove to be an appropriate instrument to deal with this fact. It is stated that by this kind of bilateral agreement, the EU could adopt similar rules from the approach of the USA, including the common control doctrine and the material difference rule, for example, to open its internal market in a controlled manner, making it more competitive. At least this would be a more conservative step for the EU to take instead of applying the international trademark exhaustion in full extent (Zappalaglio, 2015, pp. 79-86). 


\section{Concluding remarks}

The concepts of trademark exhaustion and parallel imports are rather debatable, and a unanimous approach to these concepts is not as obvious as it would seem. The presumption that parallel imports are beneficial for consumers for the reasons of offering cheaper prices and greater selection is a strong argument, although there are both supporting and opposing arguments whether the unauthorized parallel imports are truly beneficial for the market as a whole. Without doubt, consumers would be more than happy to access parallel imports freely without any kind of restrictions and worldwide international trademark exhaustion would support this kind of approach. However, the rights of the consumers are not the only rights worth protecting and the rights of the trademark proprietors should be protected as well. However, the difference between the approach of two powerful markets of the EU and the USA is an appropriate example to demonstrate this fact.

The EU has adopted the approach of regional trademark exhaustion, the Community-wide exhaustion. Parallel imports coming from outside the Community are not approved without the consent of the trademark proprietor. The approach of the USA to the concepts of trademark exhaustion and parallel imports is more complicated. The USA applies the basic approach of national trademark exhaustion. However, as the practice demonstrates, this is not the whole truth since certain exceptions apply. Namely, the exceptions to the "common control" doctrine, including the "material difference" exception, are applied. Owing to these exceptions, the approach of the USA includes more liberal traits in comparison to the approach of the EU.

When comparing the approaches of the EU and the USA to the concepts of trademark exhaustion and parallel imports, it can be seen that these approaches do differ from each other. The approach of the EU is generally more cautious towards parallel imports in comparison to the approach of the USA. Although, as seen above, the approach of the USA does not represent the view of international trademark exhaustion in full extent either. This demonstrates well the fact that these concepts are not as easy to tackle as it would seem and there are reasons why markets would approach these concepts as they do.

Neither the approach of the EU nor that of the USA is perfect. The EU's strict approach of Community-wide exhaustion is a rather protectionist approach that promotes the interests of the internal market. On the one hand, this can be seen as a strategy to avoid the abuses caused by non-EU parallel imports. On the 
other hand, one may argue that the approach of the EU is too restrictive, creating obstacles to global free trade. The negative aspects of parallel imports are avoided but at the same time the benefits of parallel imports are also lost. Similarly, for the USA, which is less restrictive, one may argue that the negative outcomes of parallel imports will be more likely to occur, while from another perspective, the market of the USA will benefit from parallel imports. This fact indicates well the problematic nature of parallel imports. There is always a certain need to compromise between the different interests, as it is rather difficult to please all the actors in an equal manner.

In addition to historical reasons, for instance, it is important to understand that the markets of the EU and the USA are different, with their own primary interests, when approaching the concepts of trademark exhaustion and parallel imports. The primary interest of the EU is to create a strong unified internal market. As appropriately argued in this article, when this is the primary goal of the Community it is understandable that facts such as free trade receive less attention. With the help of an empirical study, it is visible that the Communitywide exhaustion is sufficient for the needs of the EU for now. The EU may be labelled as "fortress Europe", but this does not seem to bother since the primary interests of the internal market are fulfilled, without being abused by aggressive non-EU parallel imports.

The USA has certain liberal traits despite the fact of not applying the international trademark exhaustion in full extent. Again, the historical reasons, for example, have had their influence making the approach of the USA somewhat different from that of the EU. Despite the fact that the idea of universality was changed to the idea of territoriality rather early, it can be seen that this universality principle has still been relevant in the legal thinking of the USA. Throughout the case law of the USA, one of the main interests of the Supreme Court has been to protect the rights of the trademark proprietor, while avoiding any confusion or deception from the consumer's side. It is well stated that the "consumer protection approach" and the "unfair competition approach" can be distinguished as important reasons to guide the approach of the USA. Through these approaches, the rights of the trademark proprietors should be protected, while the consumers should be protected from the harm of parallel imports. From the other perspective, the consumer still has the right to access parallel imports, which also benefits the parallel importers. These rights are tried to be balanced as well as possible, which has led, as a logical consequence, to certain exceptions mentioned in this article. These exceptions are rather reasonable for the trademark proprietors, as well as for the consumers and parallel importers, since parallel imports are allowed in certain situations. 
As to the possible unified approach between the markets of the EU and the USA, it seems unlikely for the time being, but not impossible. The approaches of the EU and the USA are rather different. It seems that these markets will try to focus primarily on their own interests and develop their approach as they seem fit. Of course, these markets are, and will most likely remain, important trading partners, which means that some kind of unification may be possible. As mentioned above, there is always a possibility for a bilateral agreement between these markets. In fact, it is well argued by scholars that the free trade agreement TTIP could prove to be an appropriate instrument to deal with this fact. At least this kind of agreement would be an easier step than to apply the international trademark exhaustion in full extent. Furthermore, since the consequences of parallel imports are not entirely clear, it would be advisable to have more updated data and studies that are genuinely reliable. This way the consequences of parallel imports would become more transparent, which, in turn, would make the decision of worldwide approach possible.

Samuel Dobrin is a young scholar of European business law. He is currently pursuing a Master of Law degree in European Business Law at Lund University, Sweden. Mr. Dobrin holds a bachelor's degree from the Tallinn Law School of Tallinn University of Technology. The research interests of Samuel Dobrin are mainly focused on European business law, including legal fields of intellectual property, competition law, and the European Union law in general.

Dr. Archil Chochia is a researcher at the Tallinn Law School of Tallinn University of Technology, and has been working at the university since 2009. Dr. Chochia obtained his doctoral degree from the Tallinn University of Technology in 2013. Dr. Chochia has published more than 40 publications as articles in peer-reviewed academic journals, chapters in books, doctoral dissertation and conference papers. His research fields of interest are the European Union, EU integration, EU Neighbourhood policy, Law and Technology, Georgia.

\section{References}

Abbott, F. M.; Cottier, T. \& Gurry, F. (2011), International Intellectual Property in an Integrated World Economy, $2^{\text {nd }}$ ed., New York: Wolters Kluwer Law \& Business. Altman, L. \& Pollack, M. (2015), Callmann on Unfair Competition, Trademarks and Monopolies, $4^{\text {th }}$ ed., Database updated December 2015 (Available on Westlaw). Apollinaris Co. Ltd. v. Scherer [1886], District Court of New York, Second Circuit, 27 F. (1886) 18. 
Avgoustis, I. (2012), 'Parallel imports and exhaustion of trade mark rights: should steps be taken towards an international exhaustion regime?' European Intellectual Property Review, vol. 34, no. 2, pp. 108-121.

Bently, L. \& Sherman, B. (2009), Intellectual Property Law, $3^{\text {rd }}$ ed., New York: Oxford University Press.

Birstonas, R. \& Klimkeviciute, D. (2014), 'Problematic aspects of the application of the principle of exhaustion of trademark rights in the EU (EEA) and of its interrelation with contract law: possible solutions?' European Scientific Journal, vol. 10 , no. 19 , pp. $72-100$.

Bonadio, E. (2011), 'Parallel imports in a global market: should a generalised international exhaustion be the next step?' European Intellectual Property Review, vol. 33, no. 3, pp. 153-161.

Calboli, I. (2002), 'Trademark exhaustion in the European Union: Community-wide or international? The saga continues,' Marquette Intellectual Property Law Review, vol. 6, pp. 47-90.

_ (2011), 'Market integration and (the limits of) the first sale rule in North American and European trademark law,' Santa Clara Law Review, vol. 51, no. 4, pp. 1241-1282.

(2012), 'Reviewing the (shrinking) principle of trademark exhaustion in the European Union (ten years later),' Marquette Intellectual Property Law Review, vol. 16, pp. 258-281.

Centrafarm v. Winthrop [1974], Centrafarm BV and Adriaan de Peijper v. Winthrop BV, CJEU 31.10.1974, Case 16/74.

Chen, H.-L. (2009), 'Gray marketing: does it hurt the manufacturers?' The Atlantic Economic Journal, vol. 37, no. 1, pp. 27-35. http://dx.doi.org/10.1007/s11293008-9154-6

Cheng, F.-C. (2012), 'Gaining experience from a case analysis of the parallel importation of trademark goods in the United States,' NTUT Journal of Intellectual Property Law and Management, vol. 1, no. 2, pp. 175-188.

Code of Federal Regulations (CFR), Current as of 8 June 2015.

Cook, T. (2010), EU Intellectual Property Law, New York: Oxford University Press.

Cornish, W. R.; Llewelyn, D. \& Aplin, T. (2010), Intellectual Property: Patents, Copyright, Trade Marks and Allied Rights, $7^{\text {th }}$ ed., London: Sweet \& Maxwell Limited.

Craig, P. \& Búrca, G. D. (2015), EU Law: Text, Cases, and Materials, $6^{\text {th }}$ ed., New York: Oxford University Press. http://dx.doi.org/10.1093/he/9780198714927.001.0001

Davidoff [2001], Zino Davidoff SA v. A \& G Imports Ltd and Levi Strauss \& Co. and Others v. Tesco Stores Ltd and Others, CJEU 20.11.2001, Joined cases C-414/99 to $\mathrm{C}-416 / 99$. 
EC (1988), First Council Directive 89/104/EEC of 21 December 1988 to approximate the laws of the Member States relating to trade marks (First TM Directive). (1999), Exhaustion of Trade Mark Rights: Working Document from the Commission Services, Commission Working Paper on Trademark Exhaustion, Internal Market Council, 21 June 1999, pp. 15-16. Retrieved from http://ec.europa.eu/internal_ market/indprop/docs/tm/exhaust_en.pdf [accessed 2 Aug 2016]

(2008), Directive 2008/95/EC of the European Parliament and of the Council of 22 October 2008 to approximate the laws of the Member States relating to trade marks (EU TM Directive).

- (2015), Directive (EU) 2015/2436 of the European Parliament and of the Council of 16 December 2015 to approximate the laws of the Member States relating to trade marks (New EU TM Directive).

EFTA (n.d.), Information about the EEA. Retrieved from www.efta.int/eea/eeaagreement/eea-basic-features [accessed 5 Jul 2016]

EMI v. CBS [1976], EMI Records Limited v. CBS United Kingdom Limited, CJEU 15.6.1976, Case 51/75.

Farley, C. H. (2014), 'Territorial exclusivity in U.S. copyright and trademark law,' in P.-E. Moyse (ed.) Distribution des Intangibles - La Propriété Intellectuelle dans le Commerce des Nouveaux Biens, Montreal: Éditions Thémis, pp. 45-66.

Griffiths, A. (2011), An Economic Perspective on Trade Mark Law, Cheltenham: Edward Elgar Publishing. http://dx.doi.org/10.4337/9780857936479

Grigoriadis, L. G. (2014), Trade Marks and Free Trade: A Global Analysis, Switzerland: Springer International Publishing. http://dx.doi.org/10.1007/978-3-319-04795-9

INTA (2015), International Trademark Association Position Paper on Parallel Imports, Parallel Imports Committee, August 2015. Retrieved from www.inta.org/Advocacy/ Documents/2015/INTA_PIC_Position_Paper.pdf [accessed 2 Aug 2016]

Jehoram, H. C. (1999), 'Prohibition of parallel imports through intellectual property rights,' International Review of Intellectual Property and Competition Law, vol. 30, no. 5, pp. 495-511.

Jehoram, T. C.; Nispen, C. \& Huydecoper, T. (2010), European Trademark Law: Community Trademark Law and Harmonized National Trademark Law, The Hague: Kluwer Law International.

K-Mart Corp. v. Cartier, Inc. [1988], Supreme Court of the United States, 486 US (1988) 281.

Katz, A. (2016, forthcoming), 'The economic rationale of exhaustion: distribution and post-sale restraints (21 August 2015),' in I. Caboli \& E. Lee (eds.) Research Handbook on IP Exhaustion and Parallel Imports, Cheltenham: Edward Elgar Publishing.

Katzel [1923], A. Bourjois \& Co. Inc. v. Katzel, Supreme Court of the United States, 260 US (1923) 689. 
Keeling, D.; Llewelyn, D.; Mellor, J.; Moody-Stuart, T. \& Berkeley, I. (2014), Kerly's Law of Trade Marks and Trade Names, $15^{\text {th }}$ ed., London: Sweet \& Maxwell. (Electronic version available on Westlaw).

Kerikmäe, T. \& Dutt, P. K. (2014), 'Conceptualization of emerging legal framework of e-regulation in the European Union,' In T. Kerikmae (ed.) Regulating eTechnologies in the European Union: Normative Realities and Trends, Switzerland: Springer International Publishing, pp. 7-32.

http://dx.doi.org/10.1007/978-3-319-08117-5_2

Kirtsaeng v. John Wiley \& Sons, Inc. [2013], Supreme Court of the United States, 133 S. Ct. (2013) 1351.

LaFrance, M. (2009), Understanding Trademark Law, $2^{\text {nd }}$ ed., New Providence, NJ \& San Francisco, CA: LexisNexis.

_ (2013), 'Wag the dog: using incidental intellectual property rights to block parallel imports,' Michigan Telecommunications and Technology Law Review, vol. 20, no. 1, pp. 45-120.

Lever Brothers Company v. United States [1993], United States Court of Appeals, District of Columbia Circuit, 981 F.2d (1993) 1330.

Li, C. \& Maskus, K. E. (2006), 'The impact of parallel imports on investments in costreducing research and development,' Journal of International Economics, vol. 68, no. 2, pp. 443-455. http://dx.doi.org/10.1016/j.jinteco.2005.07.006

MacGillivray, R. A. (2010), Parallel Importation, Canada: Canada Law Book.

Martin's Herend Imports, Inc v. Diamond \& Gem Trading USA [1997], United States Court of Appeals, Fifth Circuit, 112 F.3d (1997) 1296.

Maskus, K. E. (2000), 'Parallel imports,' The World Economy, vol. 23, no. 9, pp. 12691284. http://dx.doi.org/10.1111/1467-9701.00329

(2010), 'The curious economics of parallel imports,' WIPO Journal, vol. 2, no. 1, pp. $123-132$.

McCarthy, J. T. (2016), McCarthy on Trademarks and Unfair Competition, $4^{\text {th }}$ ed., March 2016 Update (Available on Westlaw).

Michaels, A. \& Norris, A. (2010), A Practical Approach to Trade Mark Law, $4^{\text {th }}$ ed., New York: Oxford University Press.

Mueller-Langer, F. (2012), 'Parallel trade and its ambiguous effects on global welfare,' Review of International Economics, vol. 20, no. 1, pp. 177-185.

http://dx.doi.org/10.1111/j.1467-9396.2011.01016.x

NERA (1999), The Economic Consequences of the Choice of a Regime of Exhaustion in the Area of Trademarks. Final Report for DGXV of the European Commission, Prepared by the National Economic Research Associates (NERA), SJ Berwin \& Co and IFF Research London, 8 February 1999. Retrieved from http://ec.europa. eu/internal_market/indprop/docs/tm/report_en.pdf [2 Aug 2016] 
Norman, H. E. (2013), Intellectual Property Law: Directions, New York: Oxford University Press.

Nyman-Metcalf, N.; Dutt, P. K. \& Chochia, A. (2014), 'The freedom to conduct business and the right to property: the EU technology transfer block exemption regulation and the relationship between intellectual property and competition law,' in T. Kerikmae (ed.) Protecting Human Rights in the EU, Berlin: Springer-Verlag pp. 37-70. http://dx.doi.org/10.1007/978-3-642-38902-3_4

Ohly, A. \& Pila, J. (2013), The Europeanization of Intellectual Property Law: Towards a European Legal Methodology, New York: Oxford University Press.

Peatman, S. (2014), 'Moving toward uniform international trademark protection: how amending the TRIPS Agreement will make parallel importing of gray goods less gray,' Southwestern Journal of International Law, vol. 20, pp. 445-465.

Phytheron International SA v. Jean Bourdon SA [1997], CJEU 20.3.1997, Case C-352/95.

Prutzman, L. D. \& Stenshoel, E. (2013), 'IP Exhaustion around the World: Differing Approaches and Consequences to the Reach of IP Protection beyond the First Sale - The Exhaustion Doctrine in the United States.' New York State Bar Association. International Law and Practice Section. Hanoi, Vietnam, Fall Meeting 2013. Retrieved from www.nysba.org/Sections/International/Seasonal_Meetings/ Vietnam/Program_3/Eric_Stenshoel_and_L__Donald_Prutzman_materials.html [accessed 2 Aug 2016]

Rai, R. K. \& Jagannathan, S. (2012), 'Parallel imports and unparallel laws: an examination of the exhaustion doctrine through the lens of pharmaceutical products,' Information \& Communications Technology Law, vol. 21, no. 1, pp. 53-89. http://dx.doi.org/10.1080/13600834.2012.644692

Ralf Sieckmann v Deutsches Patent- und Markenamt [2002], CJEU 12.12.2002, C-273/00.

Sardina, M. V. (2011), 'Exhaustion and first sale in intellectual property,' Santa Clara Law Review, vol. 51, no. 4, pp. 1055-1062.

Sebago [1999], Sebago Inc. and Ancienne Maison Dubois \& Fils SA v. G-B Unic SA, CJEU 1.7.1999, Case C-173/98.

Shen, C. (2012), 'Intellectual property rights and international free trade: new jurisprudence of international exhaustion doctrine under the traditional legal system,' Journal of International Commercial Law and Technology, vol. 7, no. 3, pp. 176-211.

Silhouette [1998], Silhouette International Schmied GmbH \& Co. KG v. Hartlauer Handelsgesellschaft mbH, CJEU 16.7.1998, Case C-355/96.

The United States Code (U.S. Code), Office of the Law Revision Counsel, The United States Code Online is current through Public Law 114-115 (28 December 2015), except for 114-195.

The United States Trademark Act of 1946, as Amended 25 November 2013. 
Treaty on European Union (TEU), Consolidated version of the 26 October 2012, Official Journal of the European Union, C 326/01.

Treaty on the Functioning of the European Union (TFEU), Consolidated version of the 26 October 2012, Official Journal of the European Union, C 326/01.

Verma, S. K. (1998), 'Exhaustion of intellectual property rights and free trade - Article 6 of the TRIPS Agreement,' International Review of Intellectual Property and Competition Law, vol. 29, no. 5, pp. 534-567.

Vrins, O. \& Schneider, M., eds. (2012), Enforcement of Intellectual Property Rights Through Border Measures: Law and Practice in the EU, $2^{\text {nd }}$ ed., Oxford: Oxford University Press.

Zappalaglio, A. (2015), 'International exhaustion of trade marks and parallel imports in the US and the EU: how to achieve symmetry?' Queen Mary Journal of Intellectual Property, vol. 5, no. 1, pp. 68-86.

Zino Davidoff SA v. CVS Corporation [2009], United States Court of Appeals, Second Circuit, 571 F.3d (2009) 238. 